\title{
イサチン誘導 体の質量スペクトル*1,2
}

(昭 和 44 年 11 月 13 日 受 理)

山田和俊 - 小中原猛雄・飯田弘忠*3

インジゴ系染料の構造研究扣よび質量スペクトルに扔ける開裂経路を決定するために，まず簡単なイサチン誘導体の質量スペク トルを測定した。それらの準安定イオンピーク，高分解能質量スペクトル，同位体ピークおよび二価イオンピークを解析しそれぞ れの開裂経路を解明した。

イサチン, 5-クロル-6-メトキシイサチンにおいては 2 個の CO が順次脱離し，インドール 5 員環部からの開裂が優先し，つい でフニリン開裂に類似の開裂パターンがみられた。なお分子イオンからの HNCO の脱離の副経路も認められた。

1-メチルイサチン, 1-メチル-5-クロルー6-メトキシイサチンに拈いては 1 個の CO が脱離したあとさらに $\mathrm{CO}$ また $\mathrm{CH}_{2} \mathrm{NH}$ を脱離した。CO を脱離した場合はベンズアゼチニゥムイオン $\left(\mathrm{C}_{7} \mathrm{H}_{6} \mathrm{~N}^{+}\right)$が必ず認められ，わずかではあるが 1 位からの脱人チル 反応も附随して表われた。全化合物にわたり $5 ， 6$ 位の塩素原子やメトキシ基の脱離は非常に怙こりにくいことがわかった。

\section{1 緒言}

現在染料の種類は非常に多く, その数は膨大なものになってい る。これらの合成, 物性についての多くの報告が知られている が, 構造研究および分析手段として有用であると考觉られる質量 スペクトルの応用についての研究は少ない1)。したがってそれら 化合物の開裂経路などについてはいまだ充分に解析されたとはい いがたい。そこで, ここに $\pi$-共役系化合物の electron impact 反応研究の一環として，インジゴ系染料の基本骨格をもつと考兄 られるイサチン誘導体をとりあげた。簡単なインドール誘導体の 質量スペクトルについては二, 三の報告 ${ }^{2 \sim 4)}$ がみられるが，イサ チン誘導体についての研究はまったく知られていない。これらイ サチン誘導体の質量スペクトルを，種々のマス技術およびミリマ スをもらいて詳細に検討し, 開裂経路をほぼ推定できたのでここ に報告したい。これらの解析は勿論インジゴ系染料の質量スペク トル解析にあたり有用な知見を与えるものである5)。

\section{2 実験}

\section{$2 \cdot 1$ 質量スペクトル測定条件}

通常の質量スペクトルは二重収束質量分析計 (日立) RMU-6 E 型を用い,イオン化電圧 $70 \mathrm{eV}$ ，全放射電流 $80 \mu \mathrm{A}$ で測定した。 イサチン, 1-メチルイサチンについては，それぞれ蒸発温度 200 ${ }^{\circ} \mathrm{C}, 180^{\circ} \mathrm{C}$ でイオンソース温度 $250^{\circ} \mathrm{C}$ における加熱導入方式を とり，5-クロル-6-メトキシイサチン，1-メチル-5-クロル-6-メ トキシイサチンについてはそれぞれソースヒーター温度 $320^{\circ} \mathrm{C}$, $240^{\circ} \mathrm{C}$ に打ける直接導入方式を採用した。また 1-メチルイサチ ンについては, 高分解能質量スペクトルを $\mathrm{C} \cdot \mathrm{E} \cdot \mathrm{C}$ 二重収束質量

*1 この報交を「染料の質量スペクトル（第1 報)」とする.

*2 マスと光反応との関係についての予報, 飯田弘忠, 小中原 猛雄, 山田和俊, 第 10 回有機ラジカル討論会要旨集, $\mathrm{p}$ 116.

*3 Kazutoshi Yamada, Takes KonAKahara, Hirotada IIDA 千葉大学工学部合成化学科: 千葉市弥生町 1 .

1) J. A. Vôllmin, P. Pachlatko, W.Simon, Helv. Chim. Acta, 52, 737 (1969).

2) C. Djerassi “M.S. of Org. Comp." Holden-Day Inc., San Francisco (1967) p. 610.

3) J.C. Powers, J. Org. Chem., 33, 2044 (1968).

4) 表 美守, 安田紘子, 藤沼好守, 杉山 登, 日化, 89 , 594 (1968).

5）山田和俊, 小中原猛雄, 飯田弘忠, 工化, 73, 984(1970).
分析計 $110 \mathrm{~B}$ 型を用い直接導入方式，イオン化電圧 $70 \mathrm{eV}$ にて 測定した。

\section{$2 \cdot 2$ 試 料}

（a）イサチン 市販品を常法により精製し TLC で単品で女 ることを確認した。

（b） 1-メチルイサチン6) 減圧下約 $40^{\circ} \mathrm{C}$ で乾燥して用いた。 $\mathrm{mp} 127^{\circ} \mathrm{C}$ 。

（c） 5-クロル-6-メトキシイサチン6), （d） 1-メチル-5-ク ロル-6-メトキシイサチン6) シリカゲルクロマトグラフィーによ り精製後減压下約 $40^{\circ} \mathrm{C}$ で乾燥して用いた。

\section{3 結果および考察}

$3 \cdot 1$ イサチン イサチンの質量スペクトルは図1のよらな開 裂経路を考えると主要ピークを説明することができる。なお図中 （）内の数字は $\mathrm{m} / \mathrm{e} 37$ 以上の各ピークについての相対強度を 示す。すなわち分子イオン $\mathrm{M}^{+}$ピーク (m/e 147) (1) と $\mathrm{M}-\mathrm{CO}$

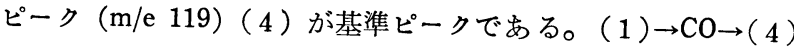
の開裂に拈ける炭素脱離の位置（2か3位）はピーク解析からは 決定できない。しかし HMO による結合次数 $P_{r s}$ の計算結果*4 は, 2 位での一酸化炭素脱離の可能性を強く支持している。

(4) は $\mathrm{CO}$ をさらにらしなって $\mathrm{C}_{6} \mathrm{H}_{5} \mathrm{~N}^{++}$(5) (m/e 91, 相

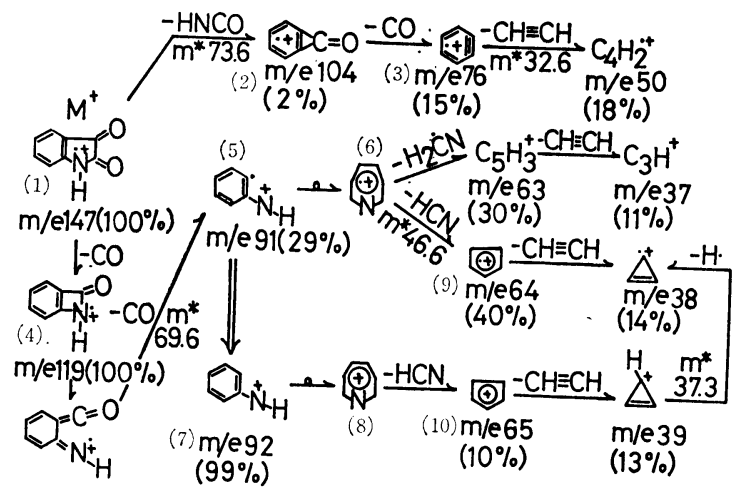

図 1

6) Y. Omote, H. Tazawa, Y. Fujinuma, N. Sugiyama, Bull. Chem. Soc. Japan, 42, 3016 (1969).

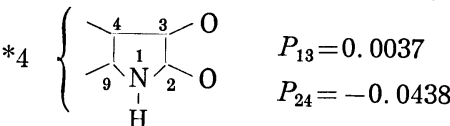


対強度 29\%) になる（準安定イオンピーク（的）が 認められた）が，この（5）は，大部分プロトン付加 した（7）(m/e 92，99\%) になり，一部は転位して （6）となり開裂する。(7) はアニリンの質量スペク トル7) に和ける M-1 イオンに相当し，その相対強度 (99\%) が非常に強いのは，図2のような共鳴による 安定化に州因するものと考えられる。アルキルベンゼ ンにおけるトロピリウムイオンのように（5）拈よび （7）が転移による環拡大をともなったアゼピニウム イオンラジカル $(6)$ およびアゼピニウムイオン $(8)$

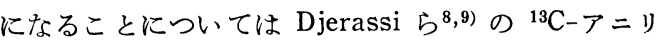
ンなどの研究により明らかにされている。これによる と（5）よりも（7）の方が，転移しやすいことにな る。（6），(8) は $\mathrm{H}_{2} \mathrm{CN}, \mathrm{HCN}$ を失って，それぞれ $\mathrm{C}_{5} \mathrm{H}_{3}{ }^{+} \mathrm{m} / \mathrm{e} 63$, およびシクロペンタジェニルイオン ジカル $\mathrm{m} / \mathrm{e} 64$ とシクロペンタジェニルイオン $\mathrm{m} / \mathrm{e}$ 65 とを生じ，さらにアセチレンを失う。（5）（また は（6））および（7）（または（8））はアセチレンを 失ってそれぞれ $\mathrm{C}_{4} \mathrm{H}_{3} \mathrm{~N}^{++} \mathrm{m} / \mathrm{e} 65, \mathrm{C}_{4} \mathrm{H}_{4} \mathrm{~N}^{+} \mathrm{m} / \mathrm{e} 66(2$ \%) を生じるとも考兄られるが*5, 後者の相対強度が 非常に小さいことによりこの開裂はこの系では無視 してもよい。（9），（10）よりアセチレンが失われる と $\mathrm{m} / \mathrm{e} 38, \mathrm{~m} / \mathrm{e} 39$ にピークを生じ, さらに $\mathrm{m} / \mathrm{e} 39$ は脱水素されて $\mathrm{m} / \mathrm{e} 38$ を生じることは, $\left(\mathrm{m}^{*}\right)$ によ り確認された。（9）は $\mathrm{C}_{6} \mathrm{H}_{4} \mathrm{~N}^{+}(\mathrm{m} / \mathrm{e} 90,15 \%)$ か らの $\mathrm{CN}$ の脱離によっても得られることが推察され る。また $\mathrm{M}^{+}$はイサチンの特徽的なスペクトルとし て m/e 104 (2) (M-HNCO, 2\%) を経て (m* が認 められた)*6, CO を失ないベンザインイオンラジカル (3) (m/e 76, 15\%) を生じる。（2）の相対強度が 弱いのは（2）の不安定性と二価イオン $\left[\mathrm{C}_{7} \mathrm{H}_{4} \mathrm{O}\right]^{2+}$ (m/e 52, 12\%) の存在などに基づくものと思われる。 (3) はさらにアセチレンを失って $\mathrm{C}_{4} \mathrm{H}_{2}{ }^{+} \mathrm{m} / \mathrm{e} 50$ を 生成する。この開裂経路は他のイサチン誘導体にもみ られた。イサチンの質量スペクトルにおいては二，三 の強い二価イオンピークが観察されたことは前述のと おりであり，これらについては後述する。イサチンの 開裂においては, $\mathrm{CO}$ と $\mathrm{HCN}, \mathrm{H}_{2} \mathrm{CN}$ および $\mathrm{HNCO}$ の脱離が主であり，インドール部分から開裂がおこる と結論される。

\section{$3 \cdot 2$ 1ーメチルイサチン}

1ーメチルイサチンの質量スペクトル結果およびその推定した開 裂経路は図 3, 図 4 に示した。（）内は図 1 と同様であり以下 これに従ら。なお \{ \} 内には高分解能質量スペクトルにおける 各イオンの質量数（計算值 Calc., 観測值 Obs.）を示した。

分子イオン $\mathrm{M}^{+}$(11) (m/e 162) が基準ピークであり，まず $\mathrm{CO}$ を失なって (12) m/e $133(33 \%)$ を生じる。(12) は $\mathrm{CH}_{2} \mathrm{NH}$,

7) P.N. Rylander, S. Meyerson, E.L. Eliel, J.D. McCollum, J. Amer. Chem. Soc., 85, 2723 (1963).

8) A. V. Robertson, C.Djerassi, J. Amer. Chem. Soc., 90, 6992 (1968).

9) K. L. Rinehart Jr., A.C. Buchholz, G. E. VanLear, J. Amer. Chem. Soc., 90, 1073 (1968).

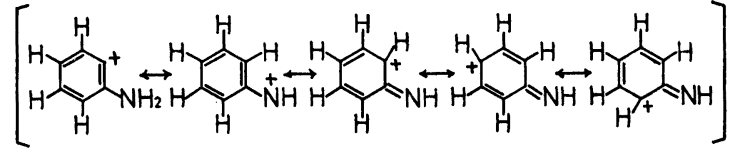

図 2

(14)

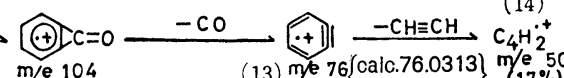

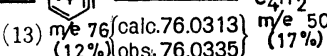

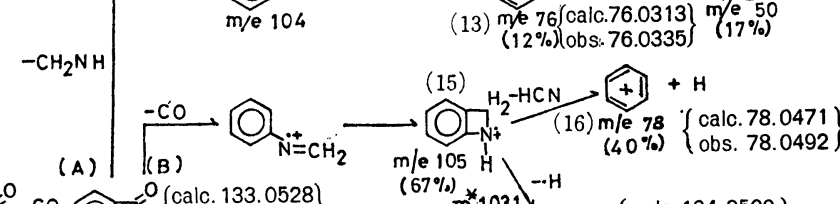
O

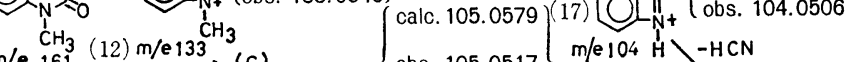

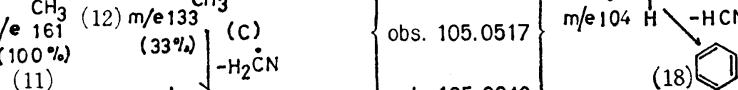

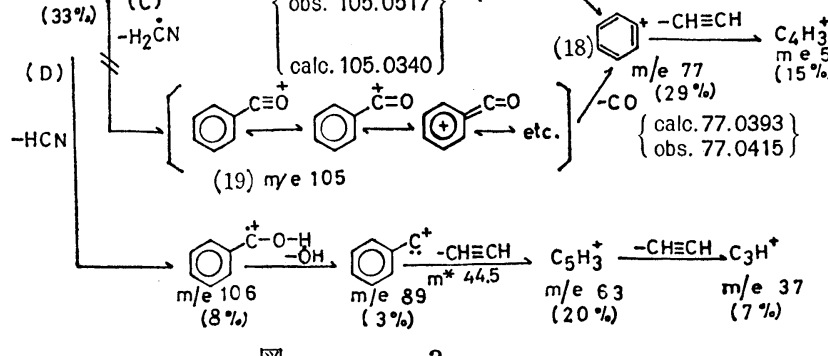

図 3

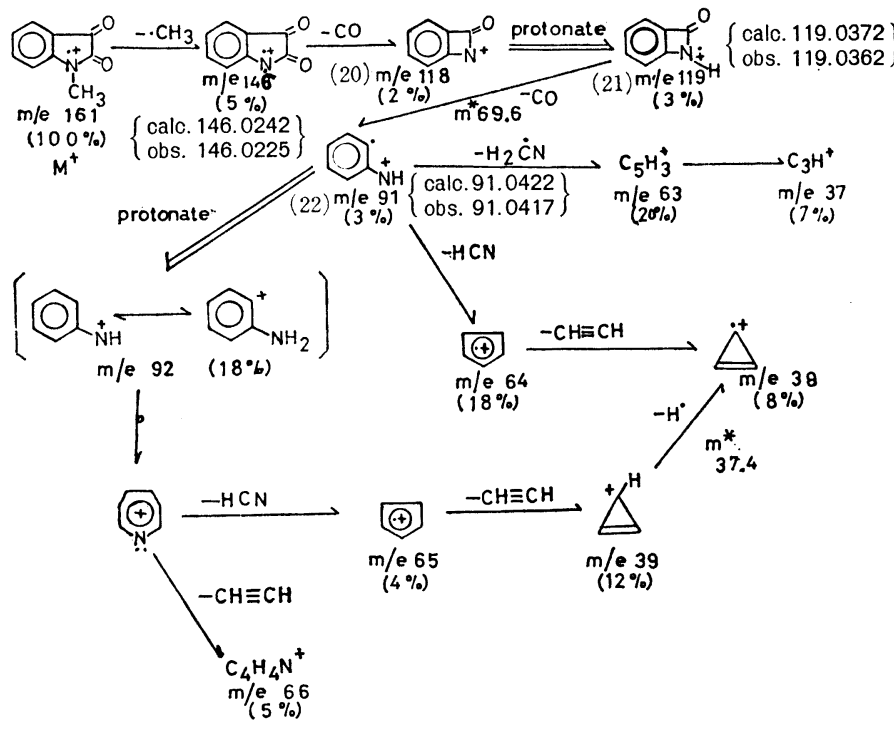

圀 4

$\mathrm{CO}, \mathrm{H}_{2} \mathrm{CN}$ および $\mathrm{HCN}$ を失らと考えられるが，(12）からこれ らのフラグメントが失われる開裂経路を，図のようにそれぞれ， (A)，(B)，(C)，および (D) とする。

(A) の経路では $\mathrm{CH}_{2} \mathrm{NH}$ を失って, イサチンの質量スペクト ルにおいて観察された（2）（m/e 104）が 89\%の相対強度であ らわれ（相当する二価イオンピークも認められた）, さらに CO,

*5 Djerassi は 3）の報告でこれを（m*)により確認してい る.

*6 ジヒドロペンゾフラン-3-オンの質量スペクトルにおいて も（2）のイオンの存在が知られている（m*が認められ ている) ; H. Budzikiewicz，C.Djerassi，D.H. Williams, "Structure Elucidation of Natural Products by M.S. (II)", Holden-Day, Inc., San Francisco (1964) p. 275 . 


\begin{tabular}{|c|c|c|c|c|c|c|c|c|c|c|}
\hline & \multirow{3}{*}{$\begin{array}{c}\text { 相対強度 } \\
\text { (計算値) } \\
(\%)\end{array}$} & \multicolumn{3}{|r|}{$\begin{array}{l}\text { 表 }{ }^{1} \\
\text { 相 }\end{array}$} & $\begin{array}{c}\text { 素の 同 位 } \\
\text { 効 } \\
\text { 強 }\end{array}$ & ピ - & $\begin{array}{l}\text { (Doub } \\
\text { （測 定 }\end{array}$ & $(\%)$ & $(\mathrm{m} / \mathrm{e})^{*}$ & \\
\hline & & \multicolumn{4}{|c|}{ 5-Chloro-6-methoxyisatin } & \multicolumn{5}{|c|}{ 1-Methyl-5-chloro-6-methoxyisatin } \\
\hline & & $\mathrm{M}^{+}$ & $\mathrm{M}-\mathrm{CO}$ & $\mathrm{M}-(2 \mathrm{CO}+1)$ & $\mathrm{M}-\left(2 \mathrm{CO}+\mathrm{CH}_{3}\right)$ & $\mathrm{M}^{+}$ & $\mathrm{M}-\mathrm{CO}$ & $\mathrm{M}-2 \mathrm{CO}$ & $\mathrm{M}-(2 \mathrm{CO}+1)$ & $\mathrm{M}-(2 \mathrm{CO}+\cdot \mathrm{CN}+1)$ \\
\hline \multirow{2}{*}{${ }^{37} \mathrm{Cl}$} & \multirow{2}{*}{32.39} & $(213)$ & $(185)$ & $(158)$ & $(142)$ & (227) & (199) & (171) & $(170)$ & (144) \\
\hline & & 36.25 & 37.33 & 38.68 & 40.76 & 39.82 & 38.72 & 34.48 & 43.55 & 35.25 \\
\hline \multirow{2}{*}{${ }^{35} \mathrm{Cl}$} & \multirow{2}{*}{100.0} & (211) & (183) & (156) & $(140)$ & $(225)$ & $(197)$ & $(119)$ & $(168)$ & $(142)$ \\
\hline & & 100.0 & 100.0 & 100.0 & 100.0 & 100.0 & 100.0 & 100.0 & 100.0 & 100.0 \\
\hline
\end{tabular}

* 上段の ( ‘) 内は $\mathrm{m} / \mathrm{e}$ の值を示し，下段の值は相対強度を示している.

アセチレンとを失ってイサチンとまったく同じ ように開裂する。この $\mathrm{m} / \mathrm{e} 104$ のピークにつ いては若干問題があるがこれについてはつぎの 項で説明する。（B）および（C）の経路におい ては（12）は $\mathrm{CO}$, または $\mathrm{H}_{2} \dot{\mathrm{C}} \mathrm{N}$ を失って $\mathrm{m} / \mathrm{e}$ 105 にそれぞれ $\mathrm{C}_{7} \mathrm{H}_{7} \mathrm{~N}^{\cdot+}, \mathrm{C}_{7} \mathrm{H}_{5} \mathrm{O}^{+}$を生じる。 （19）は図により明らかなようにその共鳴によ りかなり安定していると考えられる。しかしミ リマスの測定結果により $\mathrm{C}_{7} \mathrm{H}_{7} \mathrm{~N}$ の存在を示し ているので（C）の開裂経路はとおらないで,

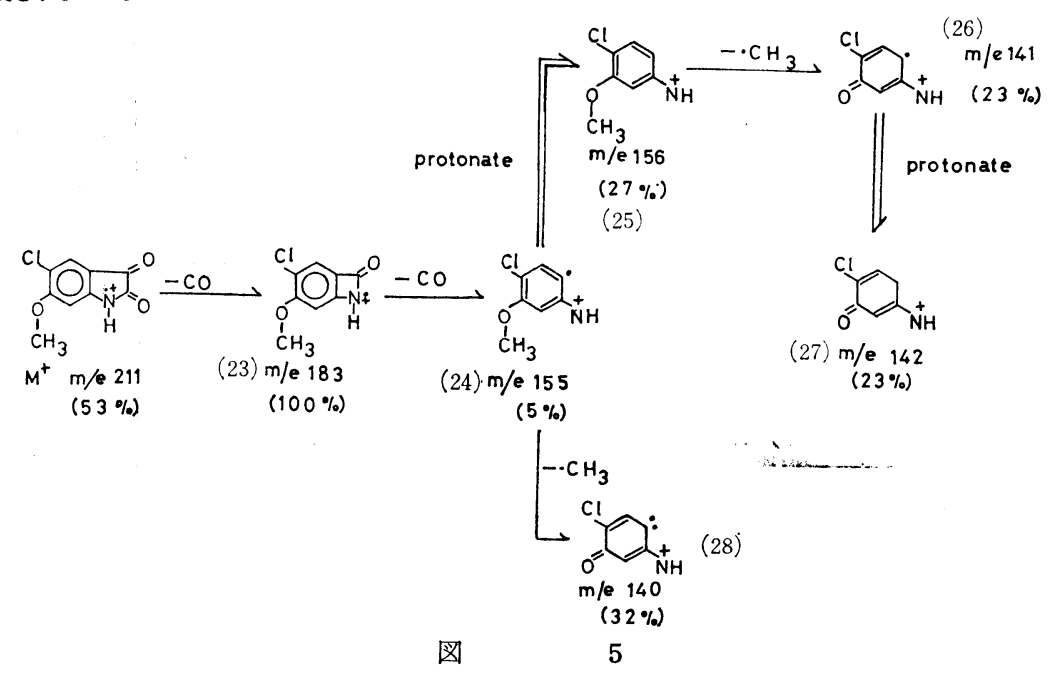

(B) の経路すなわちベンズアゼチニウムイオ ン (17) (89\%) を生じる経路をとおることに なる。ここで前にふれたように $\mathrm{m} / \mathrm{e} 104$ のピ ークとして $\mathrm{C}_{7} \mathrm{H}_{4} \mathrm{O}^{+}$と(17) の二つが考壳ら れるわけであるが，図により明らかなとおり， ミリマスの測定結果は後者すなわちベンズアゼチニウムイオンの 存在を支持している。しかし (13), (14) のピークが認められる ことより前者の存在をまったく否定することはできない。さらに これらのピークのほかに（15）および（17）より HCN がそれぞ れ脱離した(16) および（18）が図示した組成を示すことを高分 解能質量スペクトルによって確かめた。

(D) の経路では（12）より $\mathrm{HCN}$ がとれ，さらに・OH がと れたイオンが考兄れるが, この経路を無視するほど, 各ピーク の相対強度が小さい。一方, $\mathrm{M}^{+}$はメチル基を失い（図 4), 続 いて CO を失って (20) m/e 118 (2\%) を生じる。しかし (20) は不安定なためすぐプロトン付加されて (21) m/e 119 (3\%) に なり，続いて CO を失って ( $\mathrm{m} *$ が認められた) イサチンとまっ たく同じ経路を通る。しかしイサチンの場合にくらべて対応する イオンの相対強度は弱かった。これはイサチンの場合（4）が親 基準ピークと同じ相対強度を持つのに対し，1-メチルイサチンで は $\mathrm{M}-\mathrm{CH}_{3}$ イオン $(\mathrm{m} / \mathrm{e} \mathrm{146}, 5 \%)$ の相対強度が非常に弱いので (4) に対応するイオン (21) も弱くなることが推察される。(21) から（22）への開裂でイサチンの場合と同じように準安定イオン が認められたことは前述のとおりであるが, m/e 39 $\rightarrow \mathrm{m} / \mathrm{e} 38$ に おいても同様に準安定イオンピークが認められた。なお（20）は イサチンの場合と同様に $\mathrm{CO}$ を失なって $\mathrm{C}_{6} \mathrm{H}_{4} \mathrm{~N}^{+} \mathrm{m} / \mathrm{e} 90$ (14\%) になり， CN の脱離により $\mathrm{m} / \mathrm{e} 64$ を生じる経路も考えられる。 1-メチルイサチンに拈いてもイサチンの場合と同じように 2 価イ オンピークが認められたので後述する。

\section{$3 \cdot 3$ 5-クロル-6-メトキシイサチン}

5-クロルー6-メトキシイサチンの質量スペクトルは複雑である が，推定した主な開裂経路を図 5 に示す。この場合 $3 \cdot 1,3 \cdot 2$ と ことなり相当する準安定イオンピーク $\left(\mathrm{m}^{*}\right)$ は認められなかった が, ${ }^{37} \mathrm{Cl}$ と ${ }^{35} \mathrm{Cl}$ による同位体ピーク（以下 $i$-ピークとする）が 認められ，表 1 より明らかなと扤り計算值とある程度一致したの

でこれを用いて開裂経路を決定した。基準ピークは, 分子イオン $\mathrm{M}^{+} \mathrm{m} / \mathrm{e}$ の $211(53 \%)$ より $\mathrm{CO}$ が脱離したイオン $\mathrm{C}_{8} \mathrm{H}_{6} \mathrm{NO}_{2} \mathrm{Cl}^{++}$ $\mathrm{m} / \mathrm{e} 183(23)$ のピークであり，それぞれ $\mathrm{m} / \mathrm{e} 213(19 \%)$ と $\mathrm{m} / \mathrm{e} 185(37 \%)$ とに -ピークが認められた。その相対強度は計 算値とかなりの一致をみているので，塩素原子が開裂により失な われていないことを示している。 $\mathrm{m} / \mathrm{e} 183$ はさらに CO を失い m/e 155 (5\%) (24) になる。（24）は不安定なためプロトン付加 されて (25) $\mathrm{m} / \mathrm{e} 156(27 \%)$ になるかまたはメチル基を失って (28) $\mathrm{m} / \mathrm{e} 140(32 \%)$ になる。(25) の $i$-ピークは $\mathrm{m} / \mathrm{e} 158$ に $10 \%$ の相対強度で認められたが (28) の $i$-ピークは, 後述する (27) のピーク (m/e 142) と重なるため認められなかった。(25) はメトキシ置換基よりメチル基を失って（26） $\mathrm{m} / \mathrm{e} 141$ (23\%) になる。これにプロトンが付加して m/e $142(23 \%)(27)$ を生 じる。これが (28) の $i$-ピークと重なることは前述のとおりで ある。また m/e 143 にかなり強いピーク (46\%) が認められた が，これを生じる開裂経路は考えられず， m/e 142 がさらにプロ トン付加されたものではないかと考えている。以上の各ピークの 大部分に $i$-ピークが観察されたが計算值と観測值とが比較的一 致しているものについての及表 1 にあげた。しかしながら図中の 各ピークより塩素原子が脱離したピークは認められなかった。こ のことは芳香核に結合している塩素原子が非常に脱離しにくいこ とを示している。3・1，3·2 の場合と同様に二価イオンピークが 認められたので後述する。

\section{$3 \cdot 4$ 1-メチル-5-クロル-6-メトキシイサチン}

1-メチル-5-クロルー6-メトキシイサチンも複雑な開裂を示し, その開裂経路を決定するのはかなり困難である。3.3 と同様に $\left(\mathrm{m}^{*}\right)$ は認められなかったが，塩素による $i$-ピークを利用して主 な開裂経路を推定し図 6 に示した。基準ピークは $\mathrm{m} / \mathrm{e} 63$ に認め られるがその構造ははっきりしない。分子イオン $\mathrm{M}^{+} \mathrm{m} / \mathrm{e} 225$ (50\%) は二つの開裂経路をとるが，主に CO を失って m/e 197 

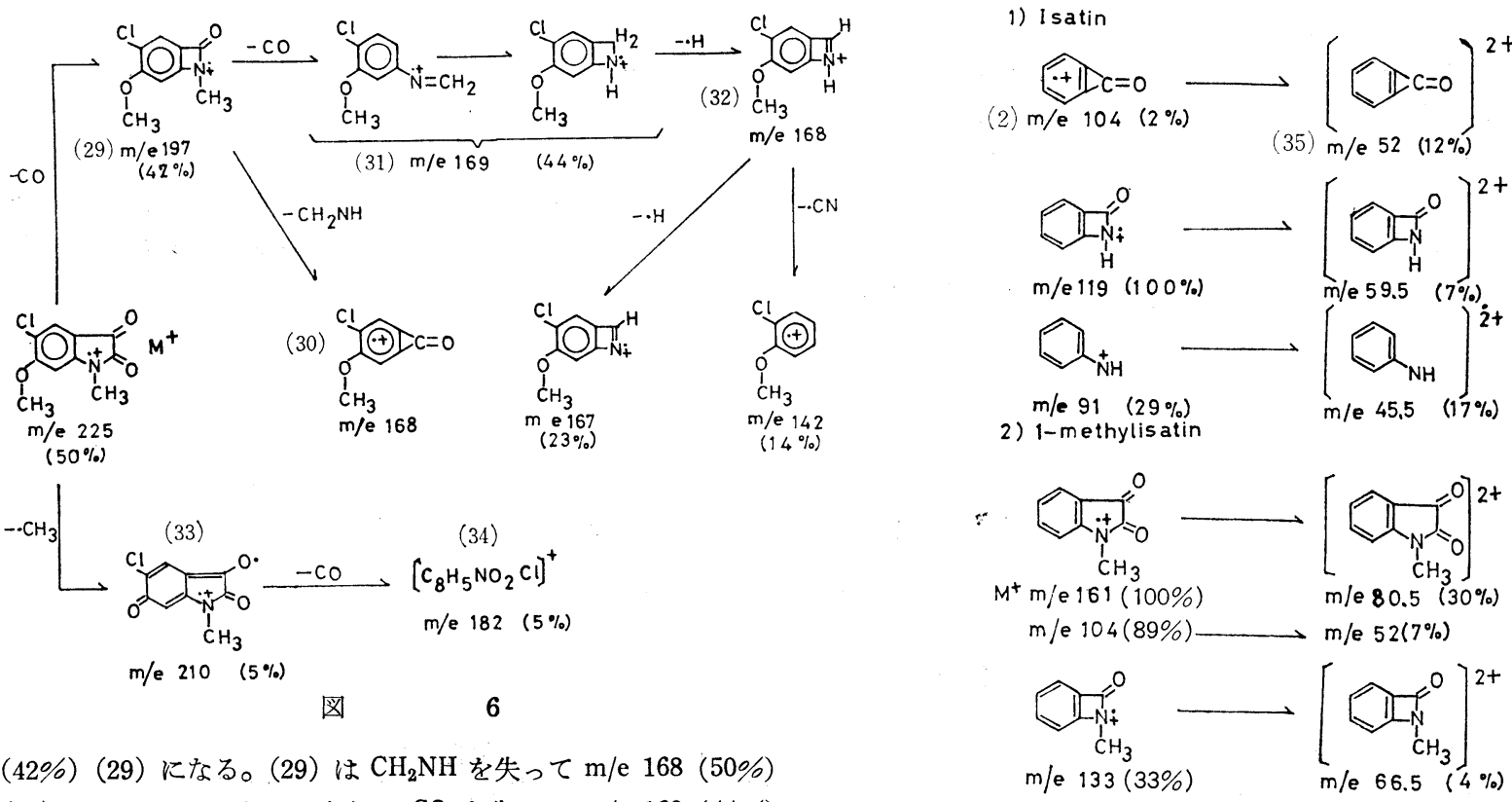

(42\%)（29）になる。（29）は $\mathrm{CH}_{2} \mathrm{NH}$ を失って m/e 168 (50\%) （30）になるか，または，さらに CO を失って m/e 169 (44\%) （31）になり，（31）は水素原子を失ってベンズアゼチニウムイオ ン構造 (32) m/e 168 (50\%) を生じる。しかし前述のとおり, $\mathrm{m} / \mathrm{e} 168$ には（30）と（32）との二つのイオンが, イサチンの場 合前者が認められ，1-メチルイサチンの場合には両方が認められ たので，この場合も両方が寄与しているものと思える。（32）は 水素原子または・CN を失ってそれぞれ $\mathrm{m} / \mathrm{e} 167, \mathrm{~m} / \mathrm{e} 142$ にピ 一クを生じる（相対強度はそれぞれ 23\%，14\%であった)。iピークは m/e 227, 199,171, 170，144 にそれぞれあらわれて いる（表 1 )。 $\mathrm{m} / \mathrm{e} 167$ に対する $i$-ピークは $\mathrm{m} / \mathrm{e} 169$ のピーク と重っていると推定される。他方 $\mathrm{M}^{+}$は 1 位またはメトキン基 からメチル基を失なって $\mathrm{m} / \mathrm{e} 210$ に相対強度 $5 \%$ のピークを生 じる。（33）はメトキシ基からメチル基が脱離した場合の図であ る。この $\mathrm{m} / \mathrm{e} 210$ のピークは $\mathrm{CO}$ を失って $\mathrm{m} / \mathrm{e} 182$ に相対強 度 $5 \%$ のピークを生じる(34)。これらの相対強度が小さいのは, この反応の起こりにくさを反映しているもので, 1-メチルイサチ ンの場合の脱メチル反応と似ている。なお 5-クロル-6-メトキシ イサチンの場合と同様に脱塩素イオンのピークは認められなかっ た。そして, 前記 3 化合物と同様に 2 価イオンピークが認められ た。

\section{5 二価イオンピーク}

2 価イオンピークは脂肪族化合物ではプロパン $\left(\mathrm{C}_{3} \mathrm{H}_{3}{ }^{2+}, \mathrm{m} / \mathrm{e}\right.$ 19.5 ${ }^{10)}$ に認められる以外あまり認められていないが，芳香族化 合物 ${ }^{11)}$ ではしばしば認められ，インドール類3)でも認められてい る。以上述べた 4 化合物の質量スペクトリにも数個の 2 価イオピ 一クが認められたので図 7,(a)，(b) にまとめた。図 7 でか印の 左辺は一価イオン, 右辺は二価イオンを示している。イサチンの 場合を除き二価,イオンピークの相対強度は非常に弱く, わずか 3 〜 4\% を示すのみであった。前述のように二価イオンピークは開 裂経路の決定に大きな役割を果している。たとえばイサチンの開 裂における（2）の存在はその相対強度が小さくてもその二価イ

10）日本化学会編, “実験化学講座（続）第 14 巻, 質量スペク トル”, 丸善 (1966) p. 214.

11) E. J. Gallegos, J. Phys. Chem., 72, 3452 (1968).

図 7 ( a )

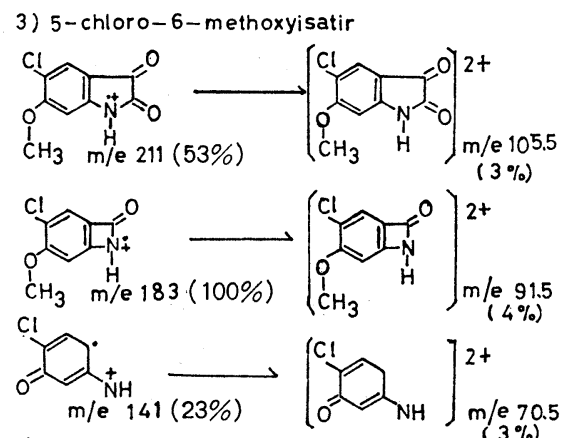

4) 1-methyl-5-chloro-6-meth oxyisatin $(3 \%)$
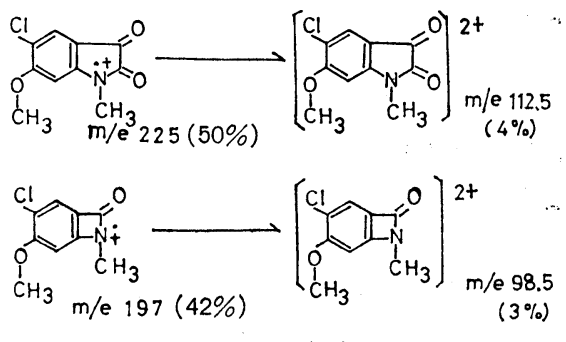

図 7 (b)

オン（35）の存在により確定される。なぜならば, 1-メチルイサ チンの場合と違って（2）以外に $\mathrm{m} / \mathrm{e} 104$ にピークを生じる開 裂が認められないからである。このほかにも同様のことが言える ので開裂決定への二価イオンピークの寄与は大きい。

\section{4 結}

以上よりイサチン類の質量スペクトルにおける開裂はCO の脱 離によるインドール部分の分解にはじまり 1 位にメチル基の置換 基がない場合（または，最初に $\mathrm{M}^{+}$よりメチル基を失った場合） は, $\mathrm{m} / \mathrm{e} 91$ に $\mathrm{C}_{6} \mathrm{H}_{5} \mathrm{~N}^{+}$を生じ，そのまま転移するかまたはプ ロトン付加されたあと転移して $\mathrm{HCN}, \mathrm{H}_{2} \mathrm{CN}$ などを失ってアニ リン同様に開裂する。 $\mathrm{C}_{6} \mathrm{H}_{5} \mathrm{~N}^{+}+$は四のような構造であるかまたは ナイトレン構造であると考兄られるなお゙ヘンゼン核上の置換塩 
- 素,メトキシ基は脱離しにくく $\mathrm{C}_{6} \mathrm{H}_{5} \mathrm{~N}^{+}$型構造にもそのま主残 っている。1 位にメチル基がある場合，大部分は，ベンジアゼチ ニウムイオンを経て開裂し，1 位での脱メチル反応は拉こりにく い。ベンゼン核上の塩素，メトキシ基による開裂のおこりにくさ は 1 位にメチル基がない場合と同じである。 $\mathrm{M}^{+}$よりの $\mathrm{CO}$ の脱 離による開裂のほか $\mathrm{M}^{+}$よりの $\mathrm{HNCO}$ または $\mathrm{CO}+\mathrm{CH}_{2} \mathrm{NH}$ の 脱離による $\mathrm{C}_{7} \mathrm{H}_{4} \mathrm{O}^{+}$を経る開裂も認められた。これらの質量ス
ペクトルの解析には, $\left(\mathrm{m}^{*}\right)$ のみでなく, 同位体ピークおよび二 価イオンピークを適宜応用し，以上の開裂経路を決定した。

（1969 年 10 月，第 10 回有機ラジカル反応討論会（大阪）部発表)

最後にこの研究を行らにあたり，貴重な試料を御提供下さった 東京教育大学理学部表美守助教授に深く感謝致します。

\title{
インジゴおよびチオインジゴ系染料の質量スペクトル*1,2
}

(昭 和 44 年 11 月 13 日 受 理)

\author{
山田 和 俊・小中原 猛雄・飯 田 弘.忠*3
}

\begin{abstract}
イサチン類の質量スペクトルの知見1)にもとづいて,インジゴ系染料の質量スペクトルを解析した。
インジゴの質量スペクトルに批いて分子イオン $\mathrm{M}^{+}$は相当する準安定イオンピークを伴い，CO を順次 2 個失5。そしてさら に水素原子を失ったあとイオンの中央より分解しデヒドロベンズフゼチニウムイオンラジカル $\mathrm{C}_{7} \mathrm{H}_{5} \mathrm{~N}^{*+}$ を生じる。このイオンは $\mathrm{M}^{+}$より分子内水素結合に基づく脱フェニル化反応によっても生じ，このあとプロトン付加されてペンッ゙アゼチニウムイオンを生 じるかまたは $\mathrm{HCN}, \cdot \mathrm{CN}$ などを失って開裂する。インジゴの場合にも1-メチルイサチン1)の場合と同様にペンッ゙アゼチニウムイ オンと $\mathrm{C}_{7} \mathrm{H}_{4} \mathrm{O}^{+}$の二つの生成が考えられた。これらの経路は $5,7,5^{\prime}, 7^{\prime}$-テトラブロムインジコの同位体ピークによっても確かめ られた。な持チインジゴ系染料の質量スペクトルについても類似の経路が認められた。
\end{abstract}

\section{1 粕言}

さきにインジゴ系染料の質量スペクトルの研究の一環として, イサチン類の質量スペクトルについて報告したが1)，今回これら の知見をもとにしてインジゴ系染料およびチオインジゴ系染料の 質量スペクトルにおける開裂経路を準安定イオンピークおよび同 位体ピーク（以下 i-ピークと略す）の比較検討により決定できた のでここに報告する。

\section{2 実験}

\section{$2 \cdot 1$ 翼量スペクトルの測定条件}

測定は日立製二重収束質量分析計 RMU-6 E 型を用 い, イオン化電圧 $70 \mathrm{eV}$, 全放射電流 $80 \mu \mathrm{A}$ で測定し

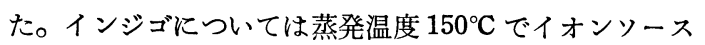
温度 $250^{\circ} \mathrm{C}$ における加熱導入方式を採用し，5，7，5', $7^{\prime}-$ テトラブロムインジゴについては，ソースヒーター温度 $320^{\circ} \mathrm{C}$ に打ける直接導入方式を, また $6,6^{\prime}$-ジェトキシ チオインジゴ, 5, 5'-ジクロル-7, 7'-ジメチルチオインジ ゴおよび 6, 6'ジクロル-4, $4^{\prime}$-ジメチルチオインジゴにつ いてはすべてソースヒーター温度 $310^{\circ} \mathrm{C}$ における直接導 入方式を採用した。

\section{$2 \cdot 2$ 試料の調製}

(a) $5,7,5^{\prime}, 7^{\prime}$-テトラブロムインジゴ*4 真空昇華 法を用い, 減圧下 $280 \sim 290^{\circ} \mathrm{C}$ で約 6 時間加熱し精製し て，TLCを用いて単品であることを確認後使用した。

*1 この報文を「染料の質量スペクトル（第 2 報）」とする.

$*_{2}$ 前報, 山田和俊, 小中原猛雄, 飯田弘忠, 工化, 73,980 (1970). （b）インジゴ 市販品を常法によりハイドロサルファイトア ルカリ溶液で還元し，これを空気酸化して精製したものを TLC を用いて単品であることを確認後使用した。

(c) 6,6'-ジエトキシチオインジゴ*4，5, 5'-ジクロル-7,7'ジメチルチオインジゴ*4 および 6, 6'-ジクロル-4, 3'-ジメチルチ オインジゴ*4 真空昇華法をもちい, 減圧下それぞれ 230～240 ${ }^{\circ} \mathrm{C}$, 約 12.5 時間 ; $270 \sim 280^{\circ} \mathrm{C}$, 約 4 時間 ; $240 \sim 260^{\circ} \mathrm{C}$ で約 9 時間加熱し精製して，TLCを用いて単品であることを確認後使 用した。

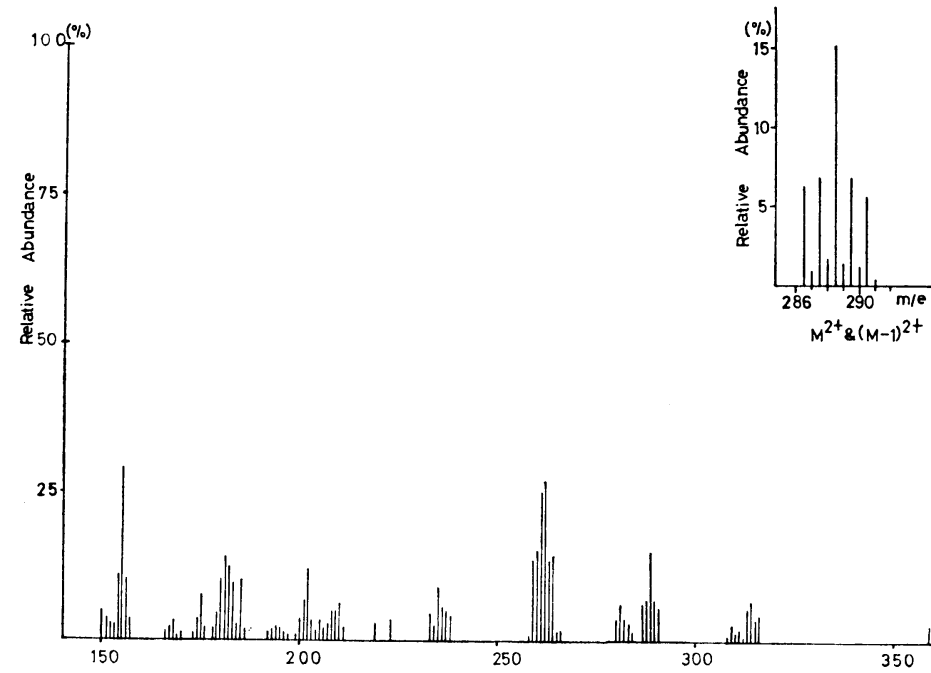

目 1 ( 1 )

*3 Kazutoshi YAMADA, Takeo KonAKAHARA, Hirotada IIDA 千葉大学工学部合成化学科：千葉市弥生町 1 .

1） *2 参照.

*4 これらの試料は三井東圧化学 K.K. より頂いたものである. 